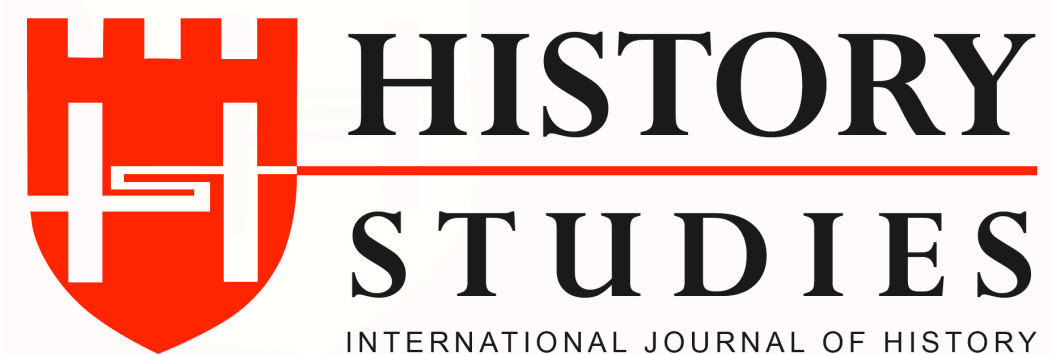

ISSN: 13094173 (Online) 1309 - 4688 (Print)

Volume 12 Issue 1, February 2020

DOI Number: 10.9737/hist.2020.831

Araştırma Makalesi

Makalenin Geliş Tarihi: 07.01.2020 Kabul Tarihi: 22.01.2020

Atıf Künyesi: Harun Tuncer, “İhanetle Sadakat Arasında: Sir James William Redhouse”, History

Studies, 12/1, Şubat 2020, s. 299-316.

\title{
İhanetle Sadakat Arasında: Sir James William Redhouse ${ }^{1}$
}

\author{
A life between loyalty and betrayal: Sir James William Redhouse
}

\author{
Dr. Harun Tuncer \\ ORCID No: 0000-0002-6569-7780 \\ İstabul Aydın Üniversitesi
}

\section{Öz}

En büyük İngiliz oryantalistlerden biri olan James William Redhouse, 1826-1853 yılları arasında 20 yılı aşkın süreyle Osmanlı Devleti adına muhtelif kurum ve görevlerde istihdam edildi. Türkiye'de başladığı Türkçe sözlük çalışmalarını ömrünün sonuna dek sürdürdü. Bugün eseri yaşıyor olsa da vefatının ardından bir buçuk asra yakın bir süre geçmiş olmasına rağmen Redhouse, ülkemizde hâlâ tam olarak tanınmamaktadır. İstisnai bir-iki çalıșma dışında hakkında söylenen ve yazılan pek çok şeyse "bilim" vasfını taşımamaktadır. Türk bilim camiasının da gündemine gelmiş olan "Müslümanlığı" meselesi spekülatif birtakım söylemlerin eseridir; ayrıca kaybolduğu söylenen misalli büyük Türkçe sözlüğünün akıbeti şimdilik meçhuldür. Bu makale çalışmasıyla Redhouse'un hayatı, gerek kültürel ve gerekse siyasî faaliyetleri daha bilinir kılınmaya çalışılmıştır.

Anahtar Kelimeler: James William Redhouse, İngiliz Oryantalist, Osmanlı Devleti, Osmanlıca Lügat, İslam.

\begin{abstract}
James William Redhouse, who was dubbed an British Orientalist, was employed by the Ottoman Empire for more than 20 years between 1826-1853 in various posts and institutions. He went on studying Turkish lexicography till his last days. Though his work still lives and referred Redhouse is not deservedly known even almost one and half century after his death. Except only one-two studies on his life and work nearly all the stuff said and talked about him bears not the naming of science. The matter of his conversion to Islam is a kind of speculation; what has happened to his "magnum opus" (A multi-volume Turkish lexicon with exemplary sentences) is still unknown. This study aims at putting forth a bit of additional information on the life and work of Redhouse, as well as his cultural and political activities.
\end{abstract}

Keywords: James William Redhouse, British Orientalist, Ottoman Empire, Ottoman Turkish Lexicon, İslam

\section{Giriş}

James William Redhouse ya da daha kısa ve meşhur deyimle Redhouse, Türkçe-İngilizce ve İngilizce-Türkçe sözlük denince akla ilk gelen isimlerden biri, belki de ilkidir. Yaklaş1k 25 yıl (1826-1853 yılları arasında) Osmanlı Devleti'nde muhtelif hizmetlerde görev alan Redhouse'un hayat hikâyesi, muhtasar biyografisini yazan, Osmanlı bürokrasisi üzerine sair

\footnotetext{
${ }^{1}$ Bu makale tezden türetilmiştir.
} 
kitap ve makaleleriyle tanıdığımız Amerikalı akademisyen Carter V. Findley'in de dediği gibi hâlâ çok da aydınlık değildir. Elimizde kendi hakkında yazdığı ve geriye bıraktığı biyografik mahiyette resmi bir kayıt da yoktur. Dolayısıyla bugün biraz amatör, biraz akademik bir tavırla hakkında bir grubun "Müslüman"dı, bir başka grubun da "ajan"dı dediği bu muamma "bilge"yi çözmek, tabir yerindeyse "deşmek" gerekiyor.

Evvela yazarın hayatı, sonra şahsiyeti ve ardından eseri inceleyip değerlendirildi ve sonuç olarak bütün bu yazılanlardan çıkan nihai tablo okurun önüne konuldu. Makalenin amacı, Redhouse'un ismini ve şahsını çoğu basmakalıp yargılardan sıyırmak ve yalnız zikredilip geçilen eserleri ve özel yazışmaları ışığında onun hakkında hakikati söylemektir. Bununla beraber yukarıda da belirttiğimiz gibi çalışmada ortaya attığımız kimi iddialar destekleyici malzemenin kısıtlılığı sebebiyle çıkarımlardan ibaret kaldı. Ancak biliyoruz ki zamanla elbette yeni belge ve bilgiler ortaya çıkacak ve eksik kalan bu resmi tamamlayacak.

Gerek Redhouse'un biyografisine dair en eski kabul ettiğimiz kaynak ${ }^{2}$ ve gerekse günümüze dek yapılan diğer çalışmalarda ortak bir nokta bulunuyor: James William Redhouse'un hayatının ilk 15 hatta 20 yılı bilinmezlerle dolu. İngiltere'de doğumuyla başlayan macerası Türkiye, Rusya, Malta, İngiltere, yeniden Türkiye ve nihayet tekrar İngiltere'ye uzandıktan sonra başladığı yerde noktalanıyor.

\section{Redhouse'un hayatı}

\subsection{Redhouse'un doğumu ve ilk yılları}

Redhouse, James ve Elizabeth çiftinin çocuğu olarak 30 Aralık 1811'de Londra yakınlarında doğ $\mathrm{du}^{3}$. Aslen Suffolk bölgesinden olan babası James'in en büyük çocuğuydu. Erken yaşta yetim kaldı. Redhouse henüz sekiz yaşındayken Christ's Hospital'a kaydedildi. Christ's Hospital'a girmesine araci olan zat William S. Angill'di'. New Monthly Magazine'de belirtildiğine göre, ailenin en büyük çocuğu olan küçük James henüz beş yaşındayken babasını kaybedince aile dostlarından birinin "delaletiyle" yerleştirilmişti Christ's Hospital'a; dolayısıyla hakkında malumatımız olmasa da Angill'in Redhouse ailesinin bir ahbabı olduğu anlaşılıyor. Bu kuruma giriş tarihi yukarıda da belirtildiği gibi 1819'du, 1819 yılının Mart ayında kuruma teslim edildi ve bir ay sonra "önlük"ü giydirilerek resmen "Christ's Hospital"lı oldu.

Christ's Hospital 1552 tarihinde Newgate, Londra'da kuruldu. Proje, dönemin İngiliz Kralı VI. Edward, Londra Başpiskoposu Nicholas Ridley ve Londra Belediye Başkanı Richard Dobbs tarafından düşünülmüştü. Asıl amaç manastırların dağılmasını müteakip fakir ve fukaranın sokaklara dolup taşmamasıydı. 2007'de Christ's Hospital Foundation ve Christ's Hospital School diye iki müstakil vakfa ayrılan ${ }^{5}$ kuruluşun resmi sitelerindeki bilgiye bakılacak olursa ortak gayeleri okulun öğrencilerinin sahip oldukları maksimum potansiyelin farkında

\footnotetext{
2 “James William Redhouse, K.C.L.S.”, New Monthly Magazine, 1880, s. 662-669.

${ }^{3}$ Charles A. Harris, Dictionary of National Biography, C. XLVII, s. 381. İnternetten eriştiğimiz "Ancestryco.uk" isimli soyağacı sitesinde yaptığımız taramada ulaştığımız 1861 tarihli nüfus sayımı kayıtlarına göre James W. Redhouse, 1812 civarında Walworth, Surrey'de doğmuştu (http://search.ancestry.co.uk/cgibin/sse.dll?h=32032\&db=uki1861\&indiv=try). Söz konusu malumatın as1l kaynağı, "Census Returns of England and Wales, 1861."

${ }^{4}$ Carter Vaughan Findley, Sir James William Redhouse, Making of a Perfect Orientalist?, İstanbul, SEV-Yay, 2006, s. 36 .

${ }^{5}$ http://www.christs-hospital.org.uk/foundation-christs-hospital-school.php (Erişim, 17/05/2012).
} 
olmalarını sağlamak ve onları hayatı kucaklayan ve onun sunacağı bütün firsatları değerlendirebilen bireyler olarak okuldan mezun etmek ${ }^{6}$.

Bütün bunların yanında bir adım daha ileri gidilecek olursa aslında karşımıza okulun adıyla mütenasip başka ve belki de esas gaye ya da okulun resmi çıkıyor: "İlmî mesleklere atılanlar kadar ticaretin pek çok sahasında mümtaz bir mertebe elde etmiș adamlar yetiștiren ve bunları dünyanın dört bir yanına salan" "7 bir kurum. Kısaca her yere ve her duruma adapte olmakta sıkıntı yaşamayan, sosyal piramidin en altından gelip en tepesine tırmanan ve/veya tırmandırılan seçkin bireyler. İleri sürülen bu görüşü destekler mahiyette bir geleneği de vardır Christ's Hospital'ın: Mezuniyet töreninde "okulun Hıristiyan değerlerine bağlılığının bir nişanesi olarak" ${ }^{8}$ mezunlara birer İncil hediye ediliyor. Bu gelenek bugün hâlâ devam etmektedir.

James William Redhouse ilk önce Christ's Hospital'ın Hertfordshire'da bulunan kısmina yerleştirilmişti. 1822 yılında da Londra'da bulunan asıl binasına gönderildi. Bir y1l sonra, yani 1823 'te "Matematik Okulu"na kabul edildi. Findley, bu okulun müstakbel bir oryantalist yahut müsteşrik ${ }^{9}$ için pek "alışılmadık" bir ocak olduğunu söylüyor. Zira belirttiğine göre bahriye sınıfı için adam yetiştiren bu mektebin müfredatı ağırlıklı olarak denizciye yarayacak teknik konulara yoğunlaşmış vaziyetteydi. Daha çok trigonometri ${ }^{10}$, seyr-i sefâin ve haritacılık (hem mimarî hem kartografik) dersleri görülüyordu. ${ }^{11}$

1819'da kabul edildiği Christ's Hospital'dan "ciddi ve tekrar eden kabahatleri" sebebiyle 1826'da kovuldu. Redhouse okuldan kovulduktan sonra bir İngiliz gemisiyle Akdeniz'e açıldı. Cezayir, Malta ve İzmir'in ardından ${ }^{12}$ Dersaadet'e geldiğinde aldığ 1 derslerin İstanbul macerasını şekillendirmekte büyük payı oldu. ${ }^{13}$

1826 yılında Christ's Hospital'dan ayrıldıktan sonra Redhouse'u İstanbul'a getiren gemi bir tüccar gemisiydi ${ }^{14}$. Bu gemi kimindi ve Redhouse o gemide hangi vasıfla bulunuyordu, işte bu nokta karanlıktır. Ne, muhtemelen kendisinin verdiği bir mülakata istinaden ${ }^{15}$ kaleme alınan, kendinden bahseden en eski makalede ve ne de herhangi farklı bir çalışmada Türkiye'de ilk yıllarına dair ayrıntılı malumata maalesef henüz ulaşılamamıştır.

Hâsılı Redhouse, Mühendishâne'de haritac ${ }^{16}$ ve/veya teknik malumatına binâen muallim ${ }^{17}$ olarak istihdâm edilmişti. Findley, bu memuriyetinin Redhouse için zor ve yabancı bir iş olmadığını, zira Matematik Okulu'nda aldığı eğitimle Mühendishâne'de verilen eğitimin

\footnotetext{
${ }^{6}$ http://www.christs-hospital.org.uk/foundation-christs-hospital-school.php (Erişim, 17/05/2012)

7 Annals of Christ's Hospital; yazar okulun mezunlarından biri olmalı, zira kitabına şahsen adını kaydetmek yerine mezunlar için bir lakap mahiyetinde kullanılan "Blue" ibaresini koymuş. Bu lakabı almalarının sebebi ise üzerlerine giydikleri "blue coat" yani siyaha çalan koyu mavi setri ("coat” maddesi, A Lexicon, English and Turkish, James W. Redhouse, İstanbul, 1911, s. 146).

${ }^{8}$ http://www.christs-hospital.org.uk/foundation-christs-hospital-school.php (Erişim, 17/05/2012).

${ }_{9}$ Kısaca oryantalizm, "din, dil, bilim, sanat, tarih gibi alanlarda Doğu’yu inceleyen ve Doğu hakkında değer yargıları üreten Batı kaynaklı müessesevî faaliyet” (Yücel Bulut, DIA, C. XXXIII, s. 428) demektir.

${ }^{10}$ Ya da o dönemin tabiriyle "müsellesât", bkz. "trigonometry", A Lexicon, English and Turkish, James W. Redhouse, s. 763.

${ }^{11}$ Findley, a.g.e., s. 37.

12 "Redhouse", a.g.m., s. 662.

${ }^{13}$ Findley, a.g.e., s. 37-38.

${ }^{14}$ LEE, a.g.e., s. 381.

${ }^{15}$ Findley, a.g.e., 76'da 1 numaralı son not.

16 "Redhouse", a.g.m., s. 662.

${ }^{17}$ Ali Rıza Seyfioğlu, aynı dipnot.
} 
paralellik arz ettiğini belirtmekte, hatta müfredatta yer alan kitaplardan bir veya birkaçının aynı olduğundan bahsetmektedir ${ }^{18}$.

Redhouse'un gelişinden sonra böyle bir memuriyet bulabilmiş olmasında iki sebep öne sürülebilir: (1) Bâbıâlî o dönemde idarî ve siyasî anlamda içeriden ve dışarıdan ciddi tehditlerle karşı karşıyayd1 ${ }^{19}$ ve dolayısıyla (2) Sultan Üçüncü Selim'le beraber başlayan ve devleti bu badireden kurtarmaya matuf askerî ve bahrî islahatlar kalifiye elemana ihtiyaç duyuyordu. Yoksa Redhouse, henüz ilk gençlik yıllarında ne pratik tecrübeye ve ne de Mühendishâne'de ders verecek eğitime sahipti.

Fakat Redhouse dilini ve kültürünü hiç bilmediği bir memlekete gelmiş ve seviyesi ne olursa olsun bir devlet kurumunda resmen çalışmaya başlamıştı. Redhouse'un da çalıştığ Osmanlı askerî mekteplerinde (Berrî ve Bahrî-i Hümayûn Mühendishâneleri) Türkçe ve Arapça öğretimi ${ }^{20}$ yanında bir de yabancı dil (o dönemde Fransızca) öğretiliyordu. Redhouse da bir vesileyle içinde bulunduğu bu mekteplerde Türkçe, Arapça ve Farsça eğitimi almış ve birkaç yıl sonra sözlük hazırlayabilecek bir müktesebâta sahip olmuştu. Yine bu mekteplerde uygulanan ders usulü daha çok yabancı kaynakların tercümesi ${ }^{21}$ ve takriri olduğundan James W. Redhouse da bu alanda kendini oldukça geliştirmişti.

Findley'e göre Redhouse, mektepte aldığı bu dil eğitimiyle de yetinmemiş, Türkçeye ve o dönem Türkçesinin temel ve esaslı kaynakları olan Arapça ve Farsçaya daha ciddi eğilmiş, bunlara ilaveten İtalyancaya hâkim bir hale gelmiş ve muhtemelen yine 1830'lardan önce Yunanca ve Almancaya da başlamıştı. Redhouse'un, bir şarkiyatçı için lüzumlu altyapıyı yine Şarklıların eliyle almış olması bizim açımızdan yaman bir çelişkidir. Fakat Redhouse, Şark'ın sahip olduğu maddî ve manevî varlıkları sömürmeye ve onu "bildikleriyle" esir etmeye kilitlenmiş bir şarkiyatçı yaklaşımını benimsememişti. Aksine edindiği hemen bütün müktesebâtı döneminin Türk sosyal ve kültürel hayatına katkı için harcadı.

Redhouse İstanbul'a gelir gelmez bahsedilen mekteplere girmiş olamazd1. Evvela ortama intibak etmeli ve kendini kabul ettirecek bir sosyal çevre edinmiş olmalıydı. Geldiği bu yeni memleketin dilinin aşinası da olmadığına göre ilk temas ettiği kimseler muhtemelen İstanbul'daki diğer İngilizler ve Levantenlerdi ${ }^{22}$. Tersane ve çevresi o dönemde mühendis ${ }^{23}$ yahut çarkçı vb. vasıflarla Fransa ve İngiltere'den ve sair Avrupa memleketlerinden gelen ve getirilen İngilizler ve diğer Avrupalılardan mahrum değildi ${ }^{24}$. Mühendishâne mekteplerine girişinde de bunların payı olabileceğini söylemek mantıken hatalı olmaz.

\footnotetext{
${ }^{18}$ Findley, a.g.e., s. 41.

19 Alaaddin Yalçınkaya, "III. Selim ve II. Mahmud Dönemi Dış Politikası”, Türkler, C. XII, Ed.: H. Celal Güzel, Kemal Çiçek, Salim Koca, Yeni Türkiye yayınları, Ankara 2002, s. 645-650.

${ }^{20}$ Mehmed Zeki Pakalın, Osmanlı Tarih Deyimleri ve Terimleri Sözlüğü, M.E.B., C. II, İstanbul 2004, s. 601-604. Burada verilen dil eğitimi konusunda Findley, zikrettiğimiz 3 dile ilaveten muhtemelen Farsçanın da öğretildiğini belirtmiştir. Bu son malumat Türk Maarif Tarihi'nde Osman Ergin tarafından da kaydedilmiştir. (C. II, İstanbul 1977, s. 319)

${ }^{21}$ Pakalın, C. II, aynı yer.

${ }^{22}$ Findley, a.g.e., s. 43.

${ }^{23}$ İdris Bostan, "Osmanlı Bahriyesinin Modernleşmesinde Yabancı Uzmanların Rolü (1785-1819)”, TD, S. 35, İstanbul 1994, s. 177.

${ }^{24}$ Gerek söz konusu yıllar ve gerek sonrasına ait Deniz Müzesi Arşivi’nde mevcut Muhasebe, Takrir defterlerinde İngiliz memurların adı sıkça zikredilir.
} 
Bu vesileyle girdiği Mühendishâne'de ilk temas kurduğu şahıslar dönemin mühendishane hocaları ve Osmanlı Devleti'ne davetle gelen Avrupalı teknik elemanlar ve muallimlerdi. Bu anlamda yerli hocalarının en başında Başhoca İshak Efendi ${ }^{25}$ geliyordu. ${ }^{26}$

Başhoca İshak Efendi'nin Mühendishâne'de vazifesine devam ederken bir taraftan da o sıralarda henüz teșekkül eden ${ }^{27}$ Tercüme Odası'nda yürüttüğü görevi, Mühendishâne'de tanıdığı Redhouse'un da ileride söz konusu odaya ve Hariciye Nezâreti'ne intisabında şüphesiz yardımcı olmuştur.

Redhouse 1827-37 tarihleri arasında muhtemelen devrin önemli ve baskın simalarından Hüsrev Paşa tarafından da biliniyor ve belki de yakinen takip ediliyordu. Namık Paşa'nın seraskerlik tarafından birtakım "istılahât-ı fenniye vaz'ına ve piyade ve süvari talimleriyle hidemât-ı dâhiliye-i askeriye" kitaplarının tercümesine memur edildiği dönemde seraskerlik makamında Hüsrev Paşa bulunuyordu. Daha çocuk denecek yaşta ${ }^{28}$ Divan-1 Hümayûn Kalemi'ne intisap eden ve $1827^{\prime}$ de bu işler için görevlendirilen Namık Paşa'yı (o zaman "efendi") o dönemde keşfeden ve onu verdiği vazifelerle etrafında tutan Hüsrev Paşa'nın hemen hemen berikinin akranı (1804-1892) olan Redhouse'u da aynı şekilde yanına ve yakınına almış olma ihtimali göz ardı edilmemelidir. Redhouse'un 1830'da Rusya seyahatini ${ }^{29}$ de yine Hüsrev Paşa'nın delaletiyle yapılmış kabul etmek mümkündür; zira yukarıda da bahsedildiği gibi 1829 'da geçici bir süre için Rusya'ya elçi olarak gönderilen Halil Rifat Paşa'nın ve maiyetinde bulunan Namık Paşa'nın Hüsrev Paşa'nın yetiştirmesi oldukları göz önünde bulundurulduğunda Redhouse'un onlara eşlik etmiş olabileceği ihtimali akla uzak gelmemektedir. ${ }^{30}$

Devletin dâhilde (Yeniçeriliğin ilgası) ve hariçte (Yunan ayaklanması) idareten ve siyaseten pek çok sıkıntıyla meşgul oluşu, bütün bunlara çare olabilmek için başvurulan çeşitli yollar ve yöntemler, idarî ve mülkî anlamda girişilen reformlar zaman bakımından Redhouse'un Osmanlı Devleti'ne gelişiyle hemen hemen denkti. Redhouse Osmanlı topraklarına ayak bastığı andan itibaren açılalı beri üzerinden çok zaman geçmemiş olan Mühendishâne ve bir zaman sonra nizam ve düzeni kısmen de olsa oturtulan Tercüme Odası onun "teknik malumatı" ve sahip olduğu "lisan kabiliyeti"yle kendisi için bulunmaz firsatlardı. Zikredilen kurumların her birinde özellikle 1820'lerin sonu ve 1830'ların başında resmen ve ne kadar, hangi faaliyetlerde bulunduğunu noktası virgülüne bilemiyoruz ${ }^{31}$; fakat anlaşılıyor ki Redhouse deruhte ettiği her işi layıkıyla yerine getirdi. İşte bu hususiyetiyle dönemin reform için çabalayan "öncülerinin" dikkatini çekmeyi başarmıştı. ${ }^{32} \mathrm{Bu}$ sayede Redhouse Osmanlı bürokrasisinde tutunabilmek imkanını bulmuştu.

\subsection{Rusya ve ardından İngiltere yolculuğu}

\footnotetext{
${ }^{25}$ Başhoca İshak Efendi hakkında bkz. Ekmeleddin İhsanoğlu, “İshak Efendi, Başhoca”, DİA, C. XXII, İstanbul 2000, s. 529-530.

${ }^{26}$ Findley, a.g.e., s. 44.

${ }^{27}$ Ali Akyıldız, Osmanlı Merkez Teşkilatından Reform, İlmî Araştırmalar, no. 6, s. 74’te 2 numaralı dipnot.

${ }^{28}$ Karal, a.g.m., s. 220. Söz konusu makalede Namık Paşa bizzat, 1816'da yani henüz 12 yaşındayken Divân-1 Hümâyûn Kalemi’ne devama başladığını yazıyor.

29 "Redhouse", a.g.m., s. 663.

${ }^{30}$ Findley, s. 82, 56 numaralı dipnot.

3120 Ekim 1840'ta Lord Ponsonby’ye yazdığı mektupta Redhouse, Osmanlı hükümeti için dokuz buçuk yıl hizmet ettiğini söylüyordu (GRE/E/503/12). Geliş tarihi 1826 olduğuna ve 1830-1833 yılları arasında Rusya'da bulunduğuna göre İstanbul'a gelişinden kısa bir süre sonra Osmanlı Devleti nezdinde göreve başlamış olduğu tahmin edilebilir.

${ }^{32}$ Findley, a.g.e., s. 48.
} 
Redhouse'un 1830 'da çıktığ Rusya seyahati ona Rus diline nüfuz imkânı vermişti ${ }^{33}$ ya da başka bir iddiaya göre Redhouse, bu seyahate Türkiye'nin doğusunda kullanılan dilleri, diğer bir deyişle Türkçenin öteki şivelerini ${ }^{34}$ öğrenmek maksadıyla çıkmıştı. Findley ise Redhouse'un Edirne Musalahası için Rusya'ya gitmiş olabileceğini ${ }^{35}$ ya da daha yüksek bir ihtimalle 182829 yılları arasında Tercüme Odası'nda yaşanan çalkantının ${ }^{36}$ bu seyahate sebep olmuş olabileceğini belirtiyor. Söz konusu dönemde Reisü'l-küttâb olan Pertev Paşa'nın tazyiki ve düşmanlığı yüzünden, odanın bozulması gerekçe ${ }^{37}$ gösterilerek, Başhoca İshak Efendi Divan-1 Hümayûn tercümanlığ 1 görevini bırakmış ve yerine Halil Esrar Efendi getirilmişti. İshak Efendi'yle münasebetinin olduğunu tahmin ettiğimiz Redhouse da durumdan etkilenmiş ve belki de sırf bu yüzden ortamın durulmasını beklemek üzere İstanbul'dan ayrılmayı tercih etmişti.

Redhouse'un Osmanlı Devleti'nden ayrılığ 1 üç y1l sürdü; 1830 'da deniz yoluyla gitmişti, 1833 'te yine deniz yoluyla, İstanbul'a döndü. İstanbul'da fazla kalmadı. Döndüğü yılın kış aylarında Malta'ya gitti. ${ }^{38}$ Findley'e göre İstanbul'dan bu erken ve görünürde sebepsiz ayrilışın âmilleri, Başhoca İshak Efendi'nin yine çeşitli vesilelerle Dersaadet'ten ve Tercüme Odası'ndaki faaliyetlerinden uzaklaştırılmasında ${ }^{39}$ aranmalıdır.

Redhouse bu üç yılı bulan seyahati sırasında, yani henüz yirmili yaşlarının başındayken ilk sözlük çalışmasına başlamış ve muhtemelen sonlandırmıştı. Zira İstanbul'dan ayrılıp 1833 kışını Malta'da geçirdikten sonra hazırladığı sözlüğü bastırmak maksadıyla 1834'te İngiltere'ye gitti. Fakat Bianchi'nin hazırladığı Türkçe-Fransızca lügatin 1835 'te piyasaya çıkmasıyla ${ }^{40}$ Redhouse'un sözlük hayali akim kaldı. ${ }^{41}$

İlk sözlük çalışması hiç beklenmedik anda akamete uğrayan genç Redhouse, muhtemelen bu hayal kırıklığının da pay sahibi olduğu bir nevi çaresizlik yüzünden, 3 yıl daha ${ }^{42}$ İngiltere'de kaldı. Bu sırada, Avrupa'nın belli başlı merkezlerinde siyaseten lüzumlu görüldüğünden yeniden daimi elçilikler açılmaya başland $1 .{ }^{43} \mathrm{O}$ dönemde Londra'ya gönderilen daimi elçimizse

33 "Redhouse", a.g.m., s. 663; Ali İhsan Gencer, "Redhouse'ın Türkçe Lügati Hakkında Mektubu”, İlmî Araștırmalar, S. 6, s. 333.

${ }^{34}$ Efecan Karagöl, Sir James William Redhouse ve İngilizlere Türkçe Öğretimi (Basılmamış Yüksek lisans tezi, 2011), s. 17.

${ }^{35}$ Bu hususta biz de onun "memuren” Rusya'ya gittiğini düşünüyoruz. Zira Redhouse (64 numaralı dipnotta ayrıntısı verilen mektupta Osmanlılar için 1839 yılı sonuna dek 3.5 yılı İngiltere'de olmak üzere 9.5 yıl hizmet ettiğini ifade ediyor. 1834 yılı başında İngiltere’ye gittiğini ve 1828-29 gibi Osmanlı hizmetine girdiğini göz önüne aldığımızda onun bu seyahatte de görevli olarak bulunduğunu tespit etmiş oluruz.)

${ }^{36}$ Findley, a.g.e., s. 49.

${ }^{37}$ Akyıldız, a.g.e., s. 75. Akyıldız zikrettiğimiz eserinde bu "uzaklaştırma"nın aslında ciddi bir gerekçesi olduğunu, 1824 başlarında İshak Efendi bulunduğu halde Fransızca dersleri yapan oda mensubu memurların pek de lisan öğrenemediklerini, dersleri veren Zenob Efendi'nin ardından duruma çare olamayan İshak Efendi'nin de odadan uzaklaştırıldığını belirtmektedir.

${ }^{38}$ Findley, a.g.e., s. 49.

${ }^{39}$ Findley, aynı yer.

40 Bianchi "Dictionnaire Turc-Français" unvanlı çalışmasını Kieffer'le birlikte çıkarmıştı ve iki cilt halinde yayımlanan eserin ilk cildindeki tarih 1835, ikinci ciltteki tarihse 1837 'ydi. J. D. Kieffer, T. X. Bianchi, Dictionnaire turc-français: a l'usage des agents diplomatiques et consulaires, des commerçants, des navigateurs, et autres voyageurs dans le Levant, 2 C., Paris 1835-1837.

41 "Redhouse", a.g.m., s. 663.

${ }^{42}$ Findley, a.g.e., s. 50.

${ }^{43}$ Unat, a.g.e., s. 20. İlk defa 1792 'de, “Avrupa'nın terakkiyât-ı cedîdesi ve Devlet-i Aliyye'nin vakt ü hâli iktizâsınca düvel-i Avrupa ile peydâ olan revâbıt-ı adîdesi düvel-i Avrupa kâidesince sefâret usulünün lüzûm-ı vaz ' $u$ tesisini..."

\section{History Studies}


Namık Paşa'ydı. Namık Paşa Redhouse'a Mühendishâne'den gerek tahsil için ve gerekse pratik anlamda işlerinde maharet kesp etmek için İngiltere'ye gelen talebelerin "nâzırı" ${ }^{44}$ olmasını teklif etti. Redhouse'a teklif edilen ilk vazife buraya gönderilen talebelere alacakları muhtelif dallardaki eğitime hazırlık için İngilizce öğretmekti; ${ }^{45}$ bir zaman sonra işi yalnız "nezâret"ten ${ }^{46}$ ibaret kaldı. Namık Paşa'dan sonra sefarete gönderilen Nuri Efendi'yle de münasebetlerini sürdürdü Redhouse. Nuri Efendi onun orada kaldığı zaman aralığında elçilik göreviyle gelenlerden ikincisiydi. O dönemde sık aralıklarla ${ }^{47}$ birkaç farklı sima daha geldi. ${ }^{48}$

Her gelen yeni isim Redhouse için aslında yeni bir "bağlantı", yeni bir aşinalık demekti. Redhouse oradayken bu isimler yoluyla resmi erkânla arasını sıcak tuttu ve öte yandan şarkiyat çalışmalarına da devam etti. Nuri Efendi' yle münasebetinde astronomi vesile olmuştu, zira adı geçen efendi "astronomiye meraklı ve meyilliydi." 49 Nuri Bey'in ardından sefarete Reşid Bey (sonradan meşhur Mustafa Reşid Paşa) getirildi. İşte o Reşid Bey Londra'da sefaretteyken Redhouse Sussex Place, Regents Park'taki sefarethanenin gediklilerindendi ${ }^{50}$.

Paris ve Londra sefaretlerinden geçirdiği 3 yılın ardından memlekete dönen Mustafa Reşid Bey 1836 'da önce Hariciye Müsteşarı ve ardından 1837 'de Hariciye Nâzırı oldu ${ }^{51}$. Artık paşa olan Mustafa Reşid Londra'daki görevinden ayrılırken yerine gelen Sarım Efendi'ye Redhouse'u teklif ve tavsiye etmeyi ihmal etmedi. Büyük ihtimalle paşanın Londra'da bulunduğu zaman zarfında Redhouse'la arası oldukça iyiydi.

\section{3. İstanbul'a dönüş}

James W. Redhouse, Londra bulunduğu 1836 y1lında evlendi. Eşi Jane Carruthers Liverpoollu bir beyefendinin, Thomas Slade'in kızıyd1 ${ }^{52}$. Redhouse evlendikten iki yıl sonra yani 1838 'de "Deraliyye'ye gitmek emeliyle" Malta'ya ulaşt1 ${ }^{53}$ ve oradan İstanbul'a geldi. İstanbul'a dönüşünü “...saltanat-l seniyyeden hisse-yâb-ı maîşet olmak arzusunda olduğuma binâen" ifadeleriyle izah ediyordu. Muhtemelen bu arizayla istenen izin verilmiş olmalı ki Redhouse 1838 'de İstanbul'a vard1.

Redhouse İstanbul'a bu ikinci gelişinde, daha önce tanıştığ 1 ve o sırada Mısır meselesi sebebiyle Londra'da bulunan Mustafa Reşid Paşa ve yine Londra sefaretinde tanıştığ

şeklinde ifade edilen zorunluluk gereği daimi elçilikler ihdas olunmuş, Sultan Üçüncü Selim'in saltanatından sonra iç ve dış gaileler sebebiyle yaşanan fasılanın ardından Sultan II. Mahmud devrinin sonlarında yine bu usule geçilmişti.

${ }^{44}$ M. Kaya Bilgegil, “Türkiye'nin İlk Talebe Müfettişi Redhouse'dur”, Kubbealtı Akademi Mecmuası, Yı1: 4, S. 4, s. 26.

45 BOA, HAT 1185/46751-A kodlu arşiv vesikasında bu durum, “... ve mersûm Londra'da akdemce dâire-i seniyyelerinde dahi hocalı hizmetinde bulunduğunu ifâde..." şeklinde belirtilmektedir.

${ }^{46}$ Bilgegil, a.g.m., s. 25. Başbakanlık Osmanlı Arşivi'nde de bu hususa dair birkaç parça evrak gördük. Mesela 14 Ekim 1868 tarihli (BOA (Devlet Arşivleri Başkanlığı Osmanlı Arşivi), Hariciye Nezareti, Londra Sefareti, (BOA. HR. SFR.3) 144/57) evrakta Redhouse dönemin Londra sefiri Kostaki Musurus Paşa'ya, "Said Efendi'nin Cambridge Üniversitesi'ne kabulü için rektör yardımcısına yazı yazdığını ve cevabını alır almaz ona bildireceğini” ifade ediyor.

${ }^{47}$ Findley, a.g.e., s. 50.

${ }^{48}$ Söz konusu sefarete gelen diğer isimler için bkz. Unat, a.g.e., s. 237.

49 "Redhouse", a.g.m., s. 663.

50 "Redhouse", s. 663.

${ }^{51}$ Beydilli, a.g.m., s. 348.

${ }^{52}$ Findley, a.g.e., s. 50.

${ }^{53}$ BOA (Devlet Arşivleri Başkanlığı Osmanlı Arşivi), Hatt-1 Hümayun, (BOA. HAT) 1185/46751-A. 
Efendi vasıtasıyla Tercüme odasına girdi; yıl $1838^{\prime}$ di. Burada ilk amiri o dönemde Divân-1 Hümâyûn tercümanı vekili ${ }^{54}$ olan Safvet Efendi'ydi.

Redhouse 1838 'de Tercüme Odası'nda işe başladığında yine muhtelif ve ilerde parlak ve yüksek mevkileri işgal edecek birtakım insanlarla birlikte oldu: Odadaki ilk yıllarında Keçecizâde Fuad Efendi (sonradan paşa) ve yine istikbalin sadrazamı ve sözlükçüsü Ahmed Vefik Bey'le (sonradan paşa) teşrik-i mesai imkanı buldu.

Redhouse resmen odaya bağlı olmasına rağmen 1839 yazından sonra yine bahriyeye dair meselelerle alakadar olmaya başladı. Bu alakanın tesisine Londra'da kurduğu ilişkiler vesile oldu; Mustafa Reşid Paşa'nın 1838'de ikinci defa Londra sefaretine getirilişi üzerine yurda dönen İbrahim Sarım Efendi, Redhouse'u dönemin kaptan-1 deryası Ahmed Fevzi Paşa'ya takdim etti. Paşa o sıralar İngiltere'den donanmanın ıslahı için davet edilen Baldwin W. Walker, nâm-1 diğer Yaver Paşa'dan ${ }^{55}$ danışmanlık alıyordu. Dolayısıyla yakın ve sıkı münasebet içindeydiler. İkilinin bu ortak mesaileri sırasında aralarında tercümanlık görevini yürüten Redhouse, Ahmed Fevzi Paşa'nın yani Osmanlı kaptan-1 deryasının en yakın adamlarından biri olmuştu.

Fevzi Paşa, 1839'da Sultan II. Mahmud'un vefatı üzerine genç Sultan Abdülmecid tahta çıktığında kaptan-1 derya idi. Sultan tahta cülusunun ardından yaklaşık on yıldır Osmanlıları rahatsız eden ve muhtelif taleplerde bulunan Mehmed Ali Paşa'yı affettiğini bildirdi. ${ }^{56}$ Yeni sultanın tahtı devralışını fırsat bilip sadareti ele geçiren Hüsrev Paşa da Çanakkale'de hareketsiz halde bulunan donanmanın harekete geçmesini emretti. Öteden beri Hüsrev Paşa'ya muhalif ${ }^{57}$ olan Fevzi Paşa da Hüsrev Paşa'ya olan kin ve düşmanlığından ötürü, ${ }^{58}$ Osmanlı donanmasını asi Mehmed Ali Paşa'ya teslim için ve onunla birleşip İstanbul'a yürümek üzere 3 Temmuz günü İskenderiye'ye hareket etti. İşte Redhouse, Danişmend'in tabiriyle bu "hain ve firari mülevves lakabıyla" tanınan Ahmed Paşa'nın ${ }^{59}$ yanındaydı. Bu ilginç ve Osmanlı ordusunun yine Mehmed Ali Paşa'dan Nizip’te aldı̆̆ darbeden sonra donanmasının da kaybı anlamına gelen hadise Redhouse'un Fevzi Paşa'yla Yaver Paşa arasında yürüttüğü aracılık görevinden ayrilmasina sebep oldu.

\footnotetext{
${ }^{54}$ Findley Safvet Efendi için 1838'de “Divan-1 Hümâyûn Tercümanı”ydı ifadesini kullanmış. Hâlbuki Safvet Efendi o tarihte Divan-1 Hümâyûn Tercümanı değil, Divân-1 Hümâyûn Tercüman vekiliydi. Divan-1 Hümâyûn Tercümanlığına ise 25 Ağustos 1840'ta atanmıştı (Akyıldız, a.g.e., 76). Findley’i bu hataya sevk eden şey Redhouse'un ileri tarihli bir mektubunda (29 Ocak 1877) Safvet Paşa'dan “Tercüme Odası'ndaki ilk amiri” olarak bahsedişi olabilir.

55 “... Walker, 15 Temmuz 1839'da binbaşı olmuştur. Bu arada Eylül 1836'dan 28 Kasım 1838'e kadar Vanguard isimli geminin komutanlığını yapmıştır. Bu görevlerini müteâkiben 1839 yılı içinde İngiliz Amirallik Dâiresi'nin izni ile Türk bahriyesinde komuta görevi almış ve rütbesi albaylığa çıkarılmıştır. 1839-1843 yılları arasında Osmanlı bahriyesinde görev yapan Walker, önceleri 'Walker Bey' daha sonra ferikliğe terfi ederek 'Yaver Paşa' olarak anılmıştır." Soydemir, Osmanlı Donanmasında Yabancı Müşavirlerin Etkileri (18 ve 19. Yüzyıllar), (İstanbul Üniversitesi Sosyal Bilimler Enstitüsü Tarih Anabilim Dalı), İstanbul 2007, s. 7.

${ }^{56}$ Uzunçarş1l1, a.g.e., s. 122.

57 Uzunçarşı1ı bu muhalefeti, aktardığı rivayetle şöyle izah ediyor: “... Rivayete nazaran, II. Mahmud'un son zamanlarında hastalığının ilerlemesinden dolayı hal'iyle büyük şehzade Abdülmecid'in iclâsını isteyen devlet adamlarının başındaki Koca Hüsrev Paşa'ya karşı mâbeyn müşiri Ahmed Fevzi Paşa'nın temsil ettiği saray erkânı Abdülmecid'in idamıyla babasının tahtında kalmasını temin etmek isterlermiş. İşte bundan dolayı Hüsrev Paşa II. Mahmud'un ölüm hastalığını çok yakından takip edip son nefesini verir vermez şiddetli bir partizan gayretiyle Abdülmecid'i derhal haberdar etmiş..."

${ }^{58}$ Findley, a.g.e., s. 52.

${ }^{59}$ Ahmed Lütfi Efendi, Vak'anüvis Ahmed Lütfi Efendi Tarihi, C. VI, Haz.: Yücel Demirel, İstanbul 1999, s. 1071
} 
Redhouse o tarihten sonra artık Hüsrev Paşa'nın emrindeydi; paşayla o dönem uzun zamandır (1832-1841) Britanya elçisi olan Lord Ponsonby arasında mahrem vasıta ${ }^{60}$ olarak görev yaptı. Aslında bu görevi ilaveten verilmiş bir görevdi, zira Redhouse o dönemde, daha evvel de işaret edildiği gibi, Tercüme Odası'nda çalışıyor ve memuru olduğu devlet adına muhtelif sefaretlerle mahrem hususlarda iletişimi yürütüyordu. ${ }^{61} \mathrm{Bu}$ malumatı elde ettiğimiz defterde "ilerüde tanzimi derdest olan ketebe mektebinde hocallk ile istihdâm olunmak üzere..." ibaresiyle Redhouse'un bu vazifelerine ek olarak bir de kâtiplere eğitim vereceği kaydedilmiştir. ${ }^{62}$ Redhouse'un bahriyeyle olan ilişkisi uzun süre devam etti. Zira donanmanın Mısır'a kaçırılmasıyla yeniden gerilen ve bu defa tamamen çıkmaza giren ilişkileri genç sultan Mısır'a harp ilanıyla yoluna sokacaktı; tabii devletin elden giden donanması ya da henüz mağlup olmuş ordusundan çok, yabancı müdahalesiyle yapacaktı bunu. ${ }^{63} \mathrm{Bu}$ müdahale sırasında mecburen yakınlaşan ve sıklaşan İngiliz-Osmanlı görüşmeleri Redhouse'un bahriyeye biraz daha sokulmasina yol açtı.

Hüsrev Paşa'nın emrinde 6 ay kadar çalıştıktan sonra ve iki taraf da bu ortak mesaiden memnun görünüyorken (Ocak 1840) Kaptan-1 Derya Mehmed Said Paşa'nın Redhouse'u maiyetinde istihdamı gündeme gelmiş ${ }^{64}$ ve:

“... Redhouse nâm tercümanın Bâb-ı Âlî̀'de i 'tâ buyrulan üç bin kuruş maaşının üzerine bin kuruş zammile dört bin kuruşa bi'l-iblâğ maiyyet-i bendegânemde istihdâmı husûsuna irâde-i aliyye-i vekâlet-penâhîleri müteallık buyrulmuş olmağın"

ifadelerine bakılırsa Said Paşa'nın arzusu yerine getirilmiş ${ }^{65}$ ve "işbu bin iki yüz elli beş senesi mâh-ı zilka'de-i şerîfesinin sekizinci gününden itibaren mâh-be-mâh Tersâne-i Âmire hazinesinden i'tâ olunmak üzere Mâliye muhasebesine kaydolunmak" ibaresinden de anlaşılacağı gibi Redhouse, paşanın maiyetine dâhil olmuştu. Burada Walker Bey’le birlikte

Volume 12

Issue 1

February

2020

${ }^{60}$ Findley, a.g.e., s. 52.
${ }^{61}$ BOA, Ayniyat Buyruldu Defteri 776, 15 C 1255 / 26 Ağustos 1839 tarihli kayit.

${ }^{62}$ Kaydın asıl sebebi de üst üste uhdesine verilen bu vazifelere karşılık Redhouse'un maaşına zam talebiydi. Evraka bakılırsa Cemaziyelâhir'in "gurresinden itibaren" Mansûre hazinesinden verilmesi kararlaştırılmıştı. Findley bu hususta ayrıca Redhouse'un muhtemelen Süleymaniye külliyesi bünyesinde açılan Mekteb-i Ulûm-1 Edebiyye'de ders verdiğini söyleyerek bu ihtimalin Redhouse'un Süleymaniye'de ders verdiğini söyleyen Robert Avery'nin dayanaksız ortaya attığı iddiaya bir mesnet teşkil edebileceğini belirtiyor. Halbuki Sezai Balcı'nın da tespit ettiği gibi Redhouse Tercüme Odası memurlarına Fransızca, tarih ve coğrafya dersleri vermişti. Bkz. Sezai Balcı, "Tanzimat Döneminde Babıali Tercüme Odası ve Yenileşme Faaliyetlerine Etkisi”, Osmanlı Modernleşmesi Reform Çağında Çözüm Arayışları, Ed. Ahmet Dönmez, İstanbul 2019.

${ }^{63}$ Findley, a.g.e., s. 52.

${ }^{64}$ Deniz Müzesi Arşivi, Şurâ-yı Bahriye 1822/154. Söz konusu kayıt numarası verilen defterin belirtilen sayfasının 2. bendinde yer alıyor. Ayrıca Redhouse'un bu tayin hakkında Lord Ponsonby’ye yazdığı mektuba bakılırsa, şahsen pek memnun kalmamış; zira kendi ifadesiyle "Maddi anlamda her ne kadar lehime olsa da (maaşına zam yapılmıştı) bu evvela bir değişikliktir, ikincisi mesele bana danışılmadı." GRE/E/503/7 (Palace Green Library, Durham Üniversitesi)

65 GRE/E/503/7. Bu mektupta yer alan ifadeler göz önünde bulundurulduğunda Redhouse'un sadrazamın hizmetindeyken Mehmed Said Paşa'nın hizmetine nakli sadrazam Hüsrev Paşa'nın tensibiyle gerçekleşmiş. Redhouse bu hadiseyi “... vezir beni gösterişsiz bir merasimle kaptan paşaya takdim etti.” şeklinde yorumluyor. Hatta öfkelendiğini de gizlemeyerek "eğitimin kıymetini bilmeyen bu kabil insanların iltifatına güvenilmeyeceğini” belirtiyor.

Aynı mektupta bıraktığı görevinin "meraklı bir yer" olduğunu, tuhaf hikâyeler dolaştığını ve acayip raporların hazırlandığını, dolayısıyla buradan ayrılmanın kendisine dokunduğunu söylüyor.

\section{History Studies}


kaptan paşanın tercümanı olarak çalışacaktı. Redhouse 14 Ocak 1840 tarihli mektupla ${ }^{66}$ durumu İngiliz elçisi Lord Ponsonby’ye de haber vermişti.

İki ay sonra bu defa Hâriciye Müsteşarı Mehmed Emin Ali Bey ${ }^{67}$ (daha sonra Ali Paşa) görüşen Serasker Mustafa Nuri Paşa ${ }^{68}$ bir tezkire vermiş ve,

"Malum-ı âli buyrulduğu vechile İngilterelü Redhouse nam mütercimin muktezâ-yı irâde-i seniyye-i şehinşâhî üzere tahkîk-i ahvâline dair atufetlû Hâriciyye Müsteşarı bendeleriyle olunan muhâbereye dair tezkire-i âlî manzûr-ı meâlî-mevfûr-ı cenâb-ı zıllullâhî buyrulmak üzere leffen savb-ı sâmîlerine irsal kılınmış olmağla mübarek ve mes' ûd hâk-pây-ı meâlî-sây-ı cenâb-ı cihan-bâniye arz u ifade buyrularak müsteșar-l mümâ-ileyh bendelerinin tahkik ve ifadesine nazaran merkumun Bâb-ı seraskerî Tercüme Odası'na alınıp alınmaması hakkında..."

ifadeleriyle Redhouse'u yanına almak amacıyla sultanın iradesine müracaat etmişti. ${ }^{69} \mathrm{Bu}$ satırlardan da anlaşıldığı gibi seraskerin bu talebi üzerine sultan, Redhouse hakkında bir soruşturma yapılmasını emretmişti. Hariciye Müsteşarı'nın Redhouse hakkındaki mütalaası ise şöyleydi:

“...mersûm Redhouse Ingilterelü olarak mukaddema Dersaadet'e gelmiş ve Frenklerin bazıları hiçbir din ile mütedeyyin olmayarak her nereye varırlar ise ol mahallin usûlüne iktizā edegeldiklerinden ve bu dahi bu takımdan olduğundan Dersaadet'te bulunduğu hengâmda ehl-i İslam sûretinde görünmüş ve ba 'dehû Rusya memâlikine ve oradan memleketi olan Londra'ya azimet etmiş olduğu çakerlerinin sefaret memuriyetiyle Londra'ya azimet-i bendegânemde işitilmiş idügü ve mersûm elsine-i müteaddide ve fenn-i hendeseye âşinâ bir adam olarak Fransa ve Ingiltere ve Türkçe lisanlarında bir lügat dahi yapmış olması ve oralarda Türkçe bilir adamın nâdir bulunması cihetiyle tahsil-i fünûn zımnında Londra'da bulunan bendelerinin muallimliği hizmetine tayin olunmuş ve umur-ı me'mûresinde hüsn-i hizmet ile mumâ-ileyhim bendeleri kendisinden hayli müteneffi 'olmuş ve şimdilik orada bir işi kalmadiğından bir hizmet-i münasibede istihdam olunmak emel ve arzusuyla bu tarafa gelmiş"

Yani müsteşara göre, Redhouse bugünkü tabirle "ateist”ti, vaziyetini kamufle için “o mahallin usulüne uy[muştu]" ve bu durum Barutçubaşı Avanes tarafindan da teyit edilmişti. Fakat Londra'da olduğu gibi dil ve hendesedeki meziyetlerinden ötürü "münasip bir hizmette" kendisinden istifade edilebilirdi. Bu soruşturma raporu üzerine seraskerin Redhouse'u yanına almak talebine cevaben;

"Bâb-ı Ser'askerî Tercüme Odası mahall-i esrâr olarak hâricden alınacakların mazbûtiyet-i hâlleri lazimeden olup eğer zikrolunan Tercüme Odasında bu makulelerin lüzumu olup da mersûmun oda-i mezkûra alınması nezd-i âlîlerinde münasip görülür ise memur kılınmak ve eğer lüzumu olmayıp da cevap verilmek lazım geldiği halde eğerçi umur-ı dâhiliyeye karışamaz iseler de şayet elçi tarafindan iltimas vuku bulup da istihdâmina mecbur olunmamak suretiyle cevap verilmek..."

şeklinde irade buyrulmuştu. Tezkire ve iradenin üslubu açıça gösteriyor ki, Redhouse'un getirilmesi düşünülen memuriyet oldukça ciddi ve mahremiyeti haizdi. O döneme kadar Osmanlı hükümetine muhtelif yer ve görevlerde 10 yıla yakın hizmeti geçmiş olmasına rağmen Redhouse'un dahi Bab-1 Seraskeri tercüme odasına tayinine ihtiyatla yaklaşılmıştı ve azami dikkat edilmesi istenmişti (Mart 1840).

Redhouse'un Serasker Paşa'nın yanına alınıp alınmadığı konusunda net bir bilgi elimizde yok. Kendisine ait mektuplarda da Mustafa Nuri Paşa'yla birlikte çalıştığına dair bir ayrıntı göremedik. Dolayısıyla söz konusu talebin yapıldığı dönemde de Redhouse, Bahriye Nezareti için çalışıyordu diyebiliriz. Zira o yıllarda artık zirveye tırmanan Mehmed Ali Paşa isyanı sırasında müttefik donanmayla Osmanlı bahriyesi arasında iletişim aracı olmuştu.

\footnotetext{
${ }^{66} \mathrm{GRE} / \mathrm{E} / 503 / 7$.

${ }^{67}$ Kemal Beydilli, “Ali Paşa (Mehmed Emin)”, DİA, C. II, İstanbul 1989, s. 425-426.

${ }^{68}$ Danişmend, a.g.e., s. 134.

${ }^{69}$ BOA (Devlet Arşivleri Başkanlığı Osmanlı Arşivi), İrade Hariciye, (BOA, İ.HR), 327/21141.
} 
Osmanlı donanmasının Ahmed Fevzi Paşa tarafından kaçırılıp Mehmed Ali Paşa'ya teslimi Osmanl1-Mısır çatışmasında bardağı taşıran son damla olmuştu. 1840'ta özellikle İngiltere, Fransa ve Rusya'nın desteğini alan sultan, Mehmed Ali Paşa gerginliğine son vermek istiyordu. Aynı yılın sonbaharında paşaya karşı girişilen seferde Redhouse ordu ve donanmayla hükümet arasındaki yazışmalara aracı oluyor, ırkdaşı kumandaların fikir, tasarı ve hatt-1 hareketlerini Türk hükümeti ve sefir Lord Ponsonby'ye aktarıyordu. Redhouse söz konusu tercümanlık hizmetini bizzat donanmayla beraber Mısır tarafına giderek değil, Tersane-i Âmire'den yürüttü. ${ }^{70}$

Bu başarıda payı olan yabancılar hem Rus hem de Osmanlı hükümetleri tarafından taltif edildi. Bu cümleden olmak üzere Osmanlı Kaptan-1 Deryası Mehmed Said Paşa ve İngiliz sefiri Lord Ponsonby'nin tavsiyesi üzerine ${ }^{71}$ Redhouse yararlıklarına karşılık "nişân-1 iftihâr"la mükâfatlandırıldı. ${ }^{72}$

Redhouse bu vazifesinden sonra o dönemde yenice teşekkül eden Bahriye Meclisi azalığına getirildi. Bir muhasebe defteri kaydına göre "riyâsetinde Liman Nâzırı saadetlü İbrahim Rahmi Bey'in" bulunduğu meclis başkanlığı "diğer bir meşguliyeti” kabul etmez bir vazifeydi ve riyasetin İbrahim Rahmi'nin uhdesinden alınıp eski İzmir Zaptiye Nâzırı Hasan Paşa'nın uhdesine verilmesi kararlaștırılmıștı. Muhtelif isimlerin aza yapıldı ̆̆ meclise Redhouse'un da, “ ... ve Ingilterelü Redhouse birkaç lisan bilerek haylice vakitten berü Tersâne-i Âmire'de mütercimlik hizmetinde istihdâm olunarak hizmet-i me'mûresinde gayreti ve fünûn-ı bahriyede mahâreti nümûdâr ve meclis-i mezkûrda lisân-âşsinâ birinin mevcûd bulunması lâzimeden idüğü âşikâr olmaktan nâş̂̀ mütercim-i mümâileyhin dahi azâlı̆̆a me'mûr ve tayîn kılınmaları ..."73 ifadelerinden aza atandığını (Şubat 1841) öğreniyoruz. Buradaki vazifesini sürdürdüğü sırada Tercüme Odası'ndaki görevine de hâlâ devam ediyordu.

Bahriye Meclisi kuruluşunun ardından beklenen ihtiyaçlara cevap veremediği düşüncesiyle feshedilmişti. Redhouse'un azalığı da haliyle düşmüş ve fakat Tercüme Odası'ndaki vazifesini ifaya devam etmişti.

1841'de Lord Ponsonby sefaret görevini tamamladiktan sonra yerine Lord Stratford Canning geldi. 1842 yılında bir zaman Londra elçisi de olan dönemin Hâriciye Nâzırı İbrahim Sarım Efendi ${ }^{74}$ Redhouse'u, yine mahrem haberleşme vasıtası olarak, Canning'e teklif etti. Teklif kabul gördü; dolayısıyla bu vazifesi "bazı sefaretler taraflarına mahremâne ifâdât-l lâzime icrâsı sûretinde istihdâm[1]" ifadeleriyle belirtilen cümledendi. 1842 aynı zamanda Redhouse'un ilk ilmî çalışması olan Müntehebât-1 Lügat-i Osmâniye isimli çalışmasının da el yazması bir nüshasının sultana takdim edildiği ve sultanın da basımını emrettiği yıldı.

\footnotetext{
${ }^{70}$ GRE/E/503/11. Redhouse Lord Ponsonby’ye hitaben “İstanbul Limanı'nda” kaleme aldığı 3 Ekim 1840 tarihli mektubunda Amiral Stopford'un yanlış bir hükümle kendisini Kandiye’ye saldığını, fakat aynı gemiyle geri geldiğini yazıyor. Bu tarihten sonra Ponsonby’ye yazdığı bütün mektupları da "Pera"dan gönderiyor.

71 GRE/E/503/11. Bu referans numarasıyla kayıtlı mektupta Redhouse, söz konusu şahısların taltiflerinin düşünüldüğünü öğrendiğini, (Kaptan paşadan) fakat kendisinin henüz taltif edilmediğini söylüyor ve Lord Ponsonby'den hükümet nezdinde kendi adına aracılık etmesini rica ediyordu. Nitekim 11 Ocak 1841 tarihli mektubunda (GRE/E/503/20) "nişanına kavuştuğunu" ve hemen 2 gün sonra kaleme aldığı diğer bir mektupta (GRE/E/503/21) da "bunu başarılarından dolayı elde ettiğinden arkadaşlarına göstermekten duyduğu mutluluğu" bildiriyordu.

72 "Redhouse", a.g.m., s. 665.

${ }^{73}$ Deniz Müzesi Arşivi, Muhasebe 157/27.

${ }^{74}$ Redhouse, (GRE/E/503/25,26) referans numaralı mektuplarda Sarım Paşa'yla aralarının "gayet iyi olduğunu, Sarım Paşa'nın kendisini, onun Sarım Paşa'yı düşündüğü kadar düşündüğünü” aktarıyor.
} 
Bir yıl sonra Redhouse İstanbul'dan yine ayrılacakt1; bu defa görevi Rusya ve İngiltere'nin aracı olduğu ve hudut meselesinin hallini gerektiren İran Musalahası'ydı. ${ }^{75} 1830$ 'larda bir dizi sınır ihlali hadisesi Osmanlı ve İran'1 karşı karşıya getirmiş ve gerginliğe sebep olan mesele İngiltere ve Rusya'nın araya girmesi ve anlaşmaya vesile olmasıyla noktalanmıştı (1847).

İngiltere'nin murahhası elçi Stratford Canning'in seçtiği William Fenwick Williams'dı. Williams 2 yıldır İstanbul Tersanesi'nde görevliydi. Bu süre zarfinda Redhouse Williams tarafından Tersane ve "ordu-yı hümayûna" dair kaleme alınan raporları tercüme ediyordu. Dolayısıyla Williams'la olan yakınlığı sebebiyle murahhas heyetin tercümanlığına da Redhouse atand1. ${ }^{76}$ Williams'1 ve rahatsızlığını belirtmesi üzerine heyete dâhil ettiği Robert Curzon'u atayan Canning, Williams'a Redhouse'un Farsça ve Türkçeden başka Akdeniz Hıristiyanlarınca (mesela Rumca) kullanılan birkaç dili bildiğini ${ }^{77}$ belirtiyor ve "vazifesinin gerektireceği her işte Redhouse'un kendisine yardımcı olabileceğini" söylüyordu. ${ }^{78}$ Heyette Osmanlı tarafını temsilen Redhouse'un Londra sefaretinden eski ahbabı Nuri Efendi vard1; fakat Erzurum'da “inme"den ötürü vefat edince ${ }^{79}$ yerine Enveri Efendi getirildi.

Belki sadece bir tercümandı, ama musalahanın tarafi olan her iki devletin de diline de hakim oluşu onun sulhün temininde merkezî bir rol üstlenmesini sağlamıştı. Nitekim sulh metnini oluşturulması esnasında Osmanlıcadan Fransızcaya ve Farsçadan İngilizceye yaptığı tercümelerin mükemmel olduğu ve nihai anlaşma metninin "tek bir kelimesinin" değiştirilmeksizin kabul edildiği belirtilmiştir.

Katlandığı bütün sıkıntılara ve gösterdiği yararlığa rağmen Redhouse İngiliz hükümeti tarafından beklediği karşı1ığını alamadığını ${ }^{81}$ düşünüyordu. Başarı yine başkalarına ihale edilmiş; Redhouse iltifat namına yalnız İran tarafından aldığ 1 "Aslan ve Güneş" nişanıyla ${ }^{82}$ yetinmek durumunda kalmıştı.

Erzurum'dan dönüşte Tercüme Odası'ndaki görevine devam etti Redhouse, ayrıca yine “mahrem iletişim vasıtası"ydı. Bu defa vasıtalık görevine İngiliz elçisinin Reşid Paşa'dan iltimasıyla ${ }^{83}$ getirilmişti.

Yine bu dönemde, 1851 yılının Temmuz'unda kurulan Encümen-i Dâniş azalığına getirildi. 40 dâhilî yani asli, 30 da haricî yani fahri üyesi olan kurulun amacı çeşitli "ilmî ve teknik eserlerin telif ve tercümesiyle Türkçenin geliştirilmesi yönünde çaba göstermek ve 1845 'ten beri kurulması düşünülen üniversitede okutulacak kitapları hazırlamaktı." ${ }^{84}$ Redhouse da diğer ecnebi emsalleri gibi bu kurula dışarıdan yardım edecekti.

\footnotetext{
${ }^{75}$ Söz konusu musalahanın Redhouse tarafından Türkçe, Fransızca ve Farsça olmak üzere üç dilde hazırlandığını bildiğimiz maddelerinin Türkçesi için bkz. Muâhedât Mecmûası, C. III, s. 5-8.

${ }^{76}$ Joseph Wolff, Narrative of A Mission to Bokhara, Londra 1847, C. 1, s. 156.

77 Turgut Subaş1, "Sir James William Redhouse (1811-1892): A Brief Outline of His Life and Works", Pax Ottomana, Studies in Memoriam Prof Dr. Nejat Göyünç, s. 677.

${ }^{78}$ Findley, a.g.e., s. 56.

79 "Redhouse", a.g.m., s. 665. Ayrıca Paris sefaretinde de bulunan Mehmed Nuri Efendi hakkında Mehmed Süreyya,

“...umûr-1 siyâsiyede ârif bir merd-i mukaddem idi” demektedir. Mehmed Süreyya, Sicill-i Osmanî, C. IV, s. 59192.

80 "Redhouse" a.g.m., 666.

${ }^{81}$ Findley, a.g.e., 58.

${ }^{82}$ A.g.m., 666.

${ }^{83}$ FO 78/734 (Findley'den naklen).

${ }^{84}$ Abdullah Uçman, "Encümen-i Dâniş", DİA, C. XI, İstanbul 1995, s. 177.
} 
Kurulun zaman içerisinde "ortak bir tarih kitabı yazmak projesi” vardı ve Redhouse da bu projede yer alıyordu. Söz konusu Türkçe tarih projesi üç kısma ayrılmıştı ve Redhouse Hazret-i Musa'dan Hazret-i Muhammed'e dek olan ikinci kısmın yazarları arasındayd1. ${ }^{85}$

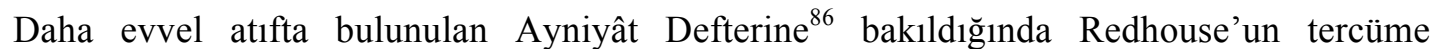
Odası'nda en yoğun faaliyet içinde olduğu dönemin bu son dönem olduğunu görülmektedir. Redhouse 1852 yılı içerisinde 120 parçadan fazla evrak çevirmişti. Bu evrakların pek çoğu İngiliz sefirine gönderilen yahut İngiliz sefiri tarafından Osmanlı devlet adamlarına gönderilen evraklard1.

Tercüme Odası'nda sürdürdüğü yoğun faaliyetlerinin yanı sıra Redhouse'un Tanzimat'tan evvel varlığ ${ }^{87}$ bilinen Oda Kütüphanesi için yürüttüğ̈̈ çalışmalar ve gösterdiği gayretten de bahsetmeliyiz. Kütüphaneye yerli yabancı pek çok kitap toplamış ve bunları oda memurlarının istifadesine sunmuştu. Redhouse Türkiye'yi terk ettiği sırada oda mensupları kütüphaneyi genişletmek amacıyla yaklaşık 500 pound toplamışlardı.

Redhouse'un bu son yıllarında içinde bulunduğu entelektüel çabalardan biri de "İstanbul Şark Cemiyeti" (Societe Orientale de Constantinople) adıyla 1853 yılının hemen başında kurulan topluluktu. Başını Henri Cayol'ün çektiği İstanbul'da yerleşmiş birtakım ecnebi bürokrat ve oryantalistlerin kurduğu cemiyet, Andreas D. Mordtmann başkanlığında haftalarca süren toplantıların ardından faaliyete geçebilmişti; Redhouse da bu cemiyetin sekreteriydi. Bahsedilen grup, cemiyet olarak ortaya çıkmadan önce Ocak 1852'de Journal Asiatique de Constantinople isimli bir dergi çıkarmışlardı. Fakat ancak tek sayı neşredebilmişlerdi. ${ }^{88}$

\subsection{Dönüşü olmayan dönüş}

Yoğun geçen 1852 yılının ardında Redhouse 1853 yılının ikinci yarısında ${ }^{89}$ Kırım Harbi patlak vermeden İstanbul'dan ayrıldı. Londra'ya dönen Redhouse'un bu ayrilışına sebep Erzurum yıllarıydı. Erzurum'da kaldıkları süreçte hem kendisinin hem de eşinin sağlığı iyiden iyiye bozulmuştu. Hâriciye Nezâreti'ne takdim ettiği bir arizada durumu şu şekilde ifade ediyor ve Osmanlı hükümetinden yardım istiyordu ${ }^{90}$ :

“Devlet-i Aliyye'nin menâfi'-i seniyyesi için leylen ve nehâran vücud ve zihnimi sarf ederek işlemiş olduğum on beş sene hizmetten sonra nâ-mizac ve alîl olduğumdan memleketime avdete mecbur oldum. Ve burada dahi bir sene istirahattan sonra yine iâde-i sthhat edemediğimden Bâb-ı Âlî tercüme odasinda tekrar memuriyetimi icra eylemek emelinden vazgeçmeye mecburiyet hâsıl olup burada vezâyifi misillü maaşı dahi cüz'î olan bir memuriyeti kabul ile kendimi bahtiyar zannetmişimdir. Fakat işbu maaş familya-yı âcizânem

${ }^{85}$ Taceddin Kayaoğlu, Türkiye'de Tercüme Müesseseleri (Karagöl, 19-20'den naklen) Yine aynı yerde Encümen üyeliğinin bir şeref addedildiği ve azaların bunu bir paye olarak kullanabileceğinin haber verildiği söylenmiş ve bu sebeple Redhouse'un da çalışmalarında zaman zaman "Member of Academy of Science of Constatinople" unvanını kullandığı belirtilmiştir.

${ }^{86}$ BOA, Ayniyat Buyruldu Defteri 776.

${ }^{87}$ Sezai Balcı, Osmanlı Devleti'nde Tercümanlık ve Bab-1 Ali Tercüme Odası, (Basılmamış Doktora tezi, Ankara 2006), s. 130. Findley'in Redhouse tarafindan kurulduğunu bahsettiği kütüphane Balcı'nın ifadelerinden anlaşıldığı kadarıyla daha evvel kurulmuştu; dolayısıyla Findley'in sözlerini kütüphaneyi o kurdu şeklinde değil de o "var olan kitaplığ 1 ihya etti" biçiminde anlamak yerinde olur. Zira orijinal ibarede bu bahis “... he later maintained, organized a library" diye geçiyor. "A" yerine "the" koymalıydı yazar.

${ }^{88}$ Fatma Müge Göçek, Rise of the Bourgeoisie Demise of Empire: Ottoman westernization and social change, Oxford 1996, s. 132. Özellikle Osmanlı başkentinde ortaya çıkan bu tip "bilim topluluklarına" dair kısmen bir değini için bkz. İsmail Doğan, "Sosyolojik Düşüncenin Osmanlı"daki Kaynakları, 'Ulûm-1 İktisadiye ve İçtimaiye Mecmuası' Örneği”, XIII. Türk Tarih Kongresi, 04-08 Ekim 1999, Ankara (III. Cilt-II. Kısım), s. 667-668.

${ }^{89}$ Danişmend, a.g.e., s. 145.

${ }^{90}$ BOA (Devlet Arşivleri Başkanlığı Osmanlı Arşivi), Hariciye Nezareti, Tercüme Odası, (BOA. HR.TO) 480/65.

\section{History Studies}


hakkında vâcibât-ı zimmetimi icrâya kâfi olmadı̆̆ından saltanat-ı seniyyenin hidemât-ı sâbıkama ve nâmizac bulunduğuma merhameten benden mukaddem bu kadar adamlar haklarında olduğu misillü hakk-ı âcizânemde dahi bir hâmî-i nîkû-kâr gibi kendisini göstermeye himmet ve inayet buyuracağını me'mûle cesaret ederim..."

Naklettiğimiz dilekçesinden de anlaşıldığı gibi Redhouse buradan temelli ayrılmak niyetiyle gitmemişti. Amacı "istirahat" ve "iade-i sıhhat" ettikten sonra yeniden dönmekti. Fakat öyle olmadı ve Redhouse "Bâb-ı Âlî tercüme odasında tekrar memuriyetimi icra eylemek emelinden vazgeçmeye mecbur" kaldı. Fakat aynı arizada belirttiği gibi efkâr ve niyetini "vüs'-i âcizâne[si] mertebe Devlet-i Aliyye'nin menâfii hakkında sarf" etmiş ve daha da önemlisi bu uğurda yaptıkları, yazdıkları ve söyledikleriyle Osmanlıların "efkârına muâvenete" gayret etmişti. Özellikle Sultan II. Abdülhamid'in tahta çıkışını müteakip Avrupa kamuoyunda Türkler aleyhinde yürütülen kampanyalara karşı durmuş ve elbette lisan sahasında dur durak tanımayan çalışmalarıyla en büyük hizmeti kültürümüz için yapmıştı.

İngiltere'ye dönünce ve artık İstanbul'a, Tercüme Odası'ndaki eski memuriyetine dönmek ihtimali de kalmayınca Redhouse 1854'te İngiliz Dışişleri Bakanlığı'nda boşalan “Doğu Dilleri Tercümanlı̆̆ $1{ }^{\prime 91}$ görevine getirildi. Bu görevi 1890 tarihine kadar sürdürdü.92 1857 tarihinde bu defa İngiliz-İran sulh müzakereleri ${ }^{93}$ sırasında Paris için terk ettiği İngiltere’yi bir daha terk etmedi. Diplomatik anlamda meşguliyeti ve dahli bu son zikrettiğimiz hadiseyle noktalanmış oluyordu. Kendisinin de belirttiği gibi Dışişleri’nde devam ettiği memuriyet "vezâyifi misillü maaşı dahi cüz'î olan bir memuriyetti". Redhouse bu memuriyetine ilaveten Royal Asiatic Society'de (Kraliyet Asya Cemiyeti) 1861-64 tarihleri arasında sekreterlik vazifesini yürüttü. ${ }^{94}$

\section{Redhouse'un ilmî çalıșmaları ve vefatı}

\section{1. İlmî çalışmaları}

İşte bu sebeplerle olsa gerek resmi yahut kamu hizmetlerinde yer almak değil, kendini ilmî çalışmalara adamayı tercih etti ya da şartlar öyle gelişti. ${ }^{95}$ Yaptığı çalışmalara kaynak temin edebilmek, hazırladığı eserlerini bastırabilmek için bir arayış içerisindeydi. Mesela Kırım Harbi esnasında İngilizlerle olan ittifakımızdan ötürü İngiliz ve Türk askerleri için "İngilizce-Türkçe ve Türkçe-İngilizce olmak üzere iki cüzden mürekkep” bir Osmanlı lisanı grameri ${ }^{96}$ ve “mükâlemeyi müştemil bulunan bir Osmanlı ve İngiliz lisanı lügati telif” ettiğini bildiriyor ${ }^{97}$ ve hurufatı bozmadan bu kitaptan birkaç yüz adet sipariş edilmesini ve baskısının ona göre yapılacağını söylüyordu.

\footnotetext{
91 "Redhouse", a.g.m., s. 667.

92 Muhtelif kaynaklarda emeklilik tarihi için 1864 yılını verirler (mesela bkz. Charles A. Harris, "James William Redhouse", Dictionary of National Biography, 1885-1900, V. 47; Yusuf Mardin, a.g.m.); fakat Findley, Redhouse'un Dışişleri Bakanlığı aktif çalışanlar listesinde 1890 tarihine kadar kaldığını yazıyor.

93 Söz konusu müzakereler Mart 1857'de gerçekleşti. Sebebi İngiltere ve İran arasında Herat'ın yeniden ilhak1 amacıyla İran'ın saldırısıyla başlayan, 1856 yılı Kasım ayıyla 1857 yılının ilk aylarına dek devam eden savaştı. Konu hakkında ayrıntılı bir çalışma olan George Henry Hunt imzalı Outram [and] Havelock's Persian Campaign isimli esere bak1labilir (özellikle sayfa 144-191).

94 Findley, a.g.e., s. 60’ta Fenwick Williams'ın Dişişleri Bakanı Earl of Clarendon'a (1853-58) takdim ettiği muhtırada Redhouse'un bakanlıktan yıllık 400 pound aldığını öğreniyoruz. Bahsettiğimiz Kraliyet Asya Sekreterliği ise Redhouse'a ekstra 90 pound gelir sağliyordu.

${ }^{95}$ A.g.e., s. 60.

${ }^{96}$ James W. Redhouse, A Turkish Vade Mecum of the Ottoman Colloquial Language in European Characters, for the Use of the British Officers, Londra 1855.

${ }^{97}$ BOA (Devlet Arşivleri Başkanlığı Osmanlı Arşivi), Hariciye Nezareti, Tercüme Odası, (BOA. HR.TO) 480/65.
} 
Kırım Harbi sona erip de hazırladığı sözlük ve gramere olan iltifat azalınca bu defa Türkiye'de 19. asrın başlarında boy gösteren ${ }^{98}$ ve giderek daha da artan "evanjelik" faaliyetler için çalışmalar yapmaya başladı. İngiliz ve Ecnebî İncil Cemiyeti (British and Foreign Bible Society) ${ }^{99}$ Redhouse'tan biraz da eskiyen Yeni Ahit tercümesini gözden geçirerek yayına hazırlamasını istedi. ${ }^{100} 1855$ 'te yaptığı İngilizce-Türkçe ve İtalyanca-Türkçe İnciller, işi sipariş eden Amerikalı misyonerlerce beğenilmedi. Redhouse ilgili cemiyet için başka tercümeler de yapt1. $^{101}$

İngiltere'de hayatının ilk safhası bu çalışmalarla başladı, ardından diğer sözlük çalışmaları ve muhtelif zamanlarla muhtelif vesilelerle kaleme aldığ 1 makalelerle meşgul oldu. ${ }^{102} 1887$ 'de ilk eşi Jane Carruthers'1 kaybetti; çok geçmeden (1888) Eliza Colquhoun'la evlendi. İleri yaşına rağmen evlenmiş olmasını belki de çocukluğunun ilk evresinde yaşadığı "kimsesizlik" sendromunun etkilerine bağlamak yanlış olmaz. Ayrıca bu evliliği Redhouse'u eski bir ahbabı olan Patrick Colquhoun'la akraba yaptı. Serveti haylice fazla olan bu "akran" kayınpederi sayesinde ahir ömründe maddi sıkıntı yaşamadı. Belki de ilerleyen yaşına rağmen sabahın 4'ünden akşamüzeri 6'ya dek çalışan Redhouse, muhtemelen "bakım ve geçim" sıkıntısı yaşamak istemiyordu ve bu kaygı son evlilik yoluyla giderilmiş oldu.

\subsection{Redhouse'un vefatı}

1884 y1lında Cambridge Üniversitesi Redhouse'a fahri doktor unvanı verdi. ${ }^{103} 1885$ 'te "Companion of the Order of Saint Michael and Saint George""104 ve 2 Haziran 1888'de "Knight's Commander" 105 nişanları verildi. Böylece Redhouse "Sir" unvanı aldı. Bu tarihten sonra fazla yaşamadı; Londra'nın Güney Hampstead bölgesinde Kilburn Priory 14 numaralı evinde ${ }^{106}$ hayata gözlerini yumdu.

Volume 12

Issue 1

February

2020

\section{Sonuç}

James W. Redhouse'un hayatı ve faaliyetlerine dair kaleme alınan bu çalışma vesilesiyle başvurmak durumunda kaldığımız ikincil kaynakların çoğu birbirinin hemen hemen tekrarından ibaretti. Hakkında yazılanların büyük bir kısmı yazar hakkında öteden beri var olan ve büyük bölümü sözlü geleneğin bir parçası olmuş "mit”lerden başka bir şey değildi. Fakat bu makalede daha önce görülmemiş birtakım birincil kaynaklara yapılan atıflarla Redhouse hakkında dikkat çeken detaylara işaret edilmiştir. Ortaya konan bu son bulgu ve bilgiler elbette erişebildiklerimizden ibarettir ve Redhouse'un hayatında elbette hâlâ karanlık bazı noktalar

${ }^{98}$ Şamil Mutlu, Osmanlı Devleti'nde Misyoner Okulları, Gökkubbe, İstanbul 2005, “Önsöz”den.

99 19. yüzyılla birlikte Avrupa'da ve Avrupa dışında hızla yaygınlaşan misyoner faaliyetler sonucu ucuz İncil'e talep artmış ve bu durum, İncil basıp dağıtan cemiyetlerin kurulmasına yol açmıştı. Uluslararası ilk İncil cemiyeti 1804 yılında Thomas Charles'nn teklifiyle kurulan British and Foreign Bible Society oldu. "Bible Societies", Encyclopedia Britannica, III, s. 587.

${ }^{100}$ Findley, a.g.e., s. 61.

${ }^{101}$ Daha fazla ayrıntı için bkz. A.g.e., s. 61-62.

${ }^{102}$ Redhouse'un kaybolan "misalli Türkçe sözlüğü”ne dair güncel bulgular için bkz. Şermin Kalafat, Bir Sözlüksel Bilmece: Redhouse'un Kayıp Sözlüğüne Ne Oldu?”, Bilig, (Yaz 2017), S. 82, s. 1-40.

${ }^{103}$ Redhouse'un Pearl-Strings isimli eserine önsöz yazan Edward G. Browne, bahse konu “önsöz"de bu unvanın zaman zaman hiç de ilmî faaliyetlerle alakası olmayan şahıslara verildiğini söylüyor ve bu durumu tenkit ediyor. Bununla birlikte Redhouse'a bu unvanın verilmesini ise sitayişle karşılıyor.

${ }^{104}$ Findley, a.g.e., s. 68.

${ }^{105}$ WM. A. Shaw, The Knights of England, Londra 1906, C. I, s. 373.

${ }^{106} 1861$ sayımına göre Redhouse, Garway Road 18 numarada oturuyordu. 1864'te ise vefat ettiğini söylediğimiz Kilburn 14 numaraya taşındi. (Londra, “City of London” arşivcisi Wendy Hawke'ın “2012/07139” referans koduyla şahsıma gönderdiği e-posta). 
bulunmaktadır. Makalenin temel bulgularından olan Müslüman olup olmadığı meselesi şimdilik bir çözüme kavuşturulmuşsa da bir "ajan” olup olmadığ kavuşturulamamıştır. Fakat bu konu hakkında da zihinlerde soru işareti yaratacak bulgulara ulaşılmıştır.

Bu makaleyle Redhouse'un hayatı, Osmanlı Devleti’nde yürüttüğü çalışmalar ve kısmen eseri hakkında ortaya konanların büyük bir bölümü, gerek arşiv kaynakları ve gerekse Redhouse'un bizzat kaleme aldığı eserlerinin mütalaasıyla ağırlıklı olarak birincil kaynaklardan derlenmiştir. Bu itibarla, okuyucuya daha taze ve önceki çabalara nispetle daha "tamam" bir Redhouse portresi sunulmuştur.

Ortaya konan bütün bu malumat ışığında denebilir ki, Redhouse'un şahsiyeti ve faaliyetleri zihinlerde daha fazla tebellür etmiştir. Fakat elbette hakikatin bir bölümü hâlâ orada bir yerde; dolayısıyla bu çalışma da bundan sonrakilere bir nebze olsun yol gösterecek ve konunun ve Redhouse'un daha fazla irdelenmesine, eserlerinin her birinin daha derin tahliline sebep olacaktır. Mesela Redhouse'a ait 30'u aşkın makale ${ }^{107}$ ve kitabın neredeyse hiçbirisi dilimize kazandırılmamıştır.

Son söz olarak denebilir ki Redhouse, hakkında hâlâ zihinlerde var olan buğulu ve şüphe uyandıran portreye rağmen, aslında gerek Türk dili ve kültürü, gerekse devrin siyasî otoritesine ciddi ve hiç de göz ardı edilemez hizmetlerde bulunmuştur. Hakkında zaman zaman dile getirilen ithamlar yersizdir denemez belki, fakat onca yıl sadakatle gördüğü bu kadar hizmet tek kalemde silinemez. Nitekim bugün hâlâ en muteber Osmanlıca sözlüklerden biri ve ilgililerinin her konuda imdadına yetişen lügat onun hazırladığ 1 Turkish and English Lexicon'dır.

\section{Kaynakça}

\section{Arşiv Belgeleri}

Devlet Arşivleri Başkanlı̆̆ Osmanlı Arşivi

Ayniyat Buyruldu Defteri

Hariciye Nezareti, Tercüme Odas1

Hariciye Nezareti, Londra Sefareti

Hatt-1 Hümayun

İrade Hariciye

Deniz Müzesi Arşivi

Palace Green Library, Durham Üniversitesi

GRE/E

The National Archives

Foreign Office

\section{Kitaplar ve Makaleler}

“Bible Societies”, Encyclopedia Britannica, C. III, s. 587.

${ }^{107} 2018$ y1lında görüştüğüm M. Murtaza Özeren, Redhouse'un muhtelif içeriğe sahip birkaç makalesini çevirerek bir kitap halinde neşretmeyi planladığını belirtmişti. Bu çabanın da en kısa zamanda bir ürün vereceğini ümit eiyorum. 
Ahmed Lütfi, (1999), Vak'anüvis Ahmed Lütfi Efendi Tarihi, Hazırlayan: Yücel Demirel, C. VI, İstanbul.

Annals of Christ's Hospital (1867), Londra.

BADEM, Candan (2011), “Amiral Adolphus Slade'in Osmanlı Donanmasındaki Hizmetleri ve Osmanlı İmparatorluğu Üzerine Gözlemleri”, Türkiyat Mecmuası, C. XXI, Bahar: 116117.

BALCI, Sezai (2019), “Tanzimat Döneminde Babıâli Tercüme Odası ve Yenileşme Faaliyetlerine Etkisi”, Osmanlı Modernleşmesi Reform Çağında Çözüm Arayışları, Ed. Ahmet Dönmez, Kitap Yayınevi, İstanbul.

BEYDİLLİ, Kemal (2006), "Mustafa Reşid Paşa", DíA, C. XXXI.

BİLGEGIL, M. Kaya (1975), "Türkiye'nin İlk Talebe Müfettişi Redhouse'dur", Kubbealtı Akademi Mecmuası, Yıl: 4, S. 4: 26.

BOSTAN, İdris (1994), "Osmanlı Bahriyesinin Modernleşmesinde Yabancı Uzmanların Rolü (1785-1819)", Tarih Dergisi, S. 35, s. 177.

C., L. Mc. (2000) “Redhouse Kimdir?” Tarih ve Toplum, C. XXXIV, s. 58-59.

ERGIN, Osman Nuri (1977), Türk Maarif Tarihi, C. II, Eser Yayınları, İstanbul.

FINDLEY, Carter Vaughn (2006), Sir James William Redhouse, Making of a Perfect Orientalist?, İstanbul.

GENCER, Ali İhsan (1998), "Redhouse'ın Türkçe Lügati Hakkında Mektubu”, İlmî Araştırmalar, S. 6, s. 333.

HAMLIN, Cyrus (1893), My Life and Times, Boston ve Chicago.

HARRIS, Charles A. (1896), "James William Redhouse", Dictionary of National Biography, C. XLVII.

İHSANOĞLU, Ekmeleddin (2000) “İshak Efendi, Başhoca”, DIA, C. XXII, İstanbul.

İNALCIK, Halil (1999), "Hüsrev Paşa, Koca”, DİA, C. XIX, İstanbul.

KALAFAT, Şermin, “Bir Sözlüksel Bilmece: Redhouse’un Kayıp Sözlüğüne Ne Oldu?”, bilig, (Yaz 2017), S. 82, s. 1-40.

KANDEL, I. L. "Classical Education", Collier's Encyclopedia, C. VI, Londra ve New York.

KARAL, Enver Ziya (1942), "Mehmed Namık Paşa'nın Hal Tercümesi”, Tarih Vesikaları, C. II, s. 221.

KARAL, Enver Ziya, Osmanlı Tarihi, C. V, Türk Tarih Kurumu, Ankara.

KAYAOĞLU, Taceddin (1998), Türkiye'de Tercüme Müesseseleri, Kitabevi, İstanbul.

LEWIS, Bernard, What Went Wrong?, Londra 2003.

MAKSUDYAN, Nazan (2007), "Bir Sözlükten Büyülenmek", Toplumsal Tarih, S. 158, s. 36.

MARDİN, Yusuf, “Tanımadığımız Redhouse”, Ylllar Boyu Tarih, S. 5, s. 26-27.

MUTLU, Şamil (2005), Osmanlı Devleti'nde Misyoner Okullarl, Gökkubbe, İstanbul.

New Monthly Magazine (1880), “James William Redhouse, K.C.L.S.”, (Haziran), s. 662-669. 
İhanetle Sadakat Arasinda: Sir James William Redhouse

ÖZCAN, Azmi (2008), "Saffet Mehmed Esad Paşa”, DİA, C. XXXV, İstanbul. (1998), "Hilafet", DİA, (Osmanlı Dönemi), C. XVI, İstanbul.

PAKALIN, Mehmed Zeki (2004), Osmanlı Tarih Deyimleri ve Terimleri Sözlüğü, C. II, İstanbul.

REDHOUSE, James W. (1855), A Turkish Vade Mecum of the Ottoman Colloquial Language in European Characters, for the Use of the British Officers, Londra.

Müntehebât-ı Lügat-i Osmâniye (1852), İstanbul.

A Lexicon, English and Turkish $(1861,1911)$, İstanbul.

Resimli-Haritalı Mufassal Osmanlı Tarihi (1972), C. VI, İstanbul.

SAYDAM, Abdullah (2006), "Mehmed Namık Paşa" DİA, C. XXXII, İstanbul.

SHAW, WM. A. (1906), The Knights of England, C. I, Londra.

SLADE, Sir Adolphus (1945), Türkiye Seyahatnâmesi ve Türk Donanması ile Yaptı̆̆ Karadeniz Seferi, Çev. Ali Rıza SEYFİĞLU, Askeri Deniz Matbaası, İstanbul.

(1833), Records of Travels in Turkey and Greece \& $c$ and of a Cruise in the Black Sea with Captain Pahsa, Londra.

SUBAŞI, Turgut, "Sir James William Redhouse (1811-1892): A Brief Outline of His Life and Works”, Pax Ottoman, Studies in Memoriam Prof Dr. Nejat Göyünç, 677.

TOKSOY, Cemal (1999), “İbrahim Sarım Paşa”, YYOA, C. I.

Türk Ansiklopedisi (1975), "Kırım Savaşı” C. XXII, Ankara.

UNAT, Faik Reşit (1992), Osmanlı Sefirleri ve Sefaretnâmeleri, Ankara.

UZUNÇARŞILI, İsmail Hakkı (1971), İzahlı Osmanlı Tarihi Kronolojisi, C. V, İstanbul.

WOLFF, Joseph (1847), Narrative of A Mission to Bokhara, C. I, Londra.

YALÇINKAYA Alaaddin, “III. Selim ve II. Mahmud Dönemi Dış Politikası”, Türkler, C. XII, Editörler: H. Celal Güzel, Kemal Çiçek, Salim Koca, Yeni Türkiye Yayınları, Ankara 2002: 645-650.

\section{Tezler ve Yayınlanmamış Çalışmalar}

BALCI, Sezai (2006), Osmanl Devleti'nde Tercümanlık ve Bab-l Ali Tercüme Odası, Yayınlanmamış Doktora Tezi, Ankara Üniversitesi Sosyal Bilimler Enstitüsü Tarih Anabilim Dalı, Ankara.

KARAGÖL, Efecan (2011), Sir James William Redhouse ve İnilizlere Türkçe Öğretimi, Basılmamış Yüksek Lisans Tezi, Abant İzzet Baysal Üniversitesi Sosyal Bilimler Enstitüsü, Bolu.

SOYDEMIR, Selman (2007), Osmanlı Donanmasında Yabancı Müşavirlerin Etkileri (18 ve 19. Yüzylllar), İstanbul Üniversitesi Sosyal Bilimler Enstitüsü Tarih Anabilim Dalı, İstanbul.

\section{Internet}

http://en.wikipedia.org/wiki/Christ\%27s_Hospital

http://www.christs-hospital.org.uk/foundation-christs-hospital-school.php 